\title{
Penerapan Pendidikan Karakter Peduli Lingkungan Melalui Program Adi Wiyata di SMK Negeri Kalibaru Sebagai Upaya dalam Mendukung Gerakan Banyuwangi Merdeka Dari Plastik
}

\author{
Harjianto*, Rohmatul Fitria Febyanti, Yuli Kartika Efendi \\ Universitas PGRI Banyuwangi \\ *Correspondence email: hr.bwin@gmail.com, febbyanti384@gmail.com, yulikartikaefendi@gmail.com
}

\begin{abstract}
Abstrak. Kehidupan manusia erat sekali hubungannya dengan lingkungan namun masih kurang rasa kepedulian dan tanggung jawabnya terhadap lingkungan, sehingga perlu diterapkan pendidikan karakter peduli lingkungan. Pendidikan karakter peduli lingkungan adalah proses pengembangan sikap sadar sebagai bagian dari lingkungan, sehingga berupaya mencegah dan memperbaiki kerusakan alam serta berusaha melestarikan lingkungan hidup demi generasi yang akan datang. Tujuan penelitian ini adalah untuk mengetahui Bagaimanakah implementasi pendidikan karakter peduli lingkungan melalui Program Adiwiyata pada peserta didik di SMK Negeri Kalibaru dalam menyuksekan Program Banyuwangi Merdeka dari Plastik. Metode penelitian yang di gunakan dalam penelitian ini adalah kualitatif. Subyek dalam penelitian ini adalah Kepala Sekolah, Pendidik, dan peserta didik. Pengumpulan data dilakukan dengan teknik observasi, teknik wawancara, dan teknik dokumentasi. Teknik analisis data yang digunakan adalah teknik analisis interaktif yang meliputi pengumpulan data, reduksi data, penyajian data, kemudian menarik suatu kesimpulan. Hasil penelitian menunjukan bahwa pendidikan karakter peduli lingkungan melalui program Adiwiyata sejalan dengan program pemerintah Kabupaten Banyuwangi yaitu merdeka dari plastik dan program tersebut berjalan dengan baik. Adapun program kegiatan tersebut meliputi program Jum'at bersih, Jum'at sehat, Jum'at taqwa, piket rutin harian dan mingguan, dan program bebas dari sampah plastik. Selain itu juga membatasi penjualan makanan yang menggunakan media plastik, serta menghimbau agar warga sekolah membawa tempat makanan dan minuman dari rumah. Melalui program tersebut peserta didik lebih peduli menjaga kelestarian dan kebersihan lingkungan ini terbukti dari kondisi lingkungan sekolah SMK Negeri Kalibaru yang bersih dan asri.
\end{abstract}

Kata kunci: Pendidikan karakter peduli lingkungan; Adiwiyata; Merdeka dari plastik

Abstract. Human life is closely related to the environment but still lacks a sense of concern and responsibility for the environment, so it is necessary to implement character education caring for the environment. Character education that cares for the environment is a process of developing a conscious attitude as part of the environment, so that it seeks to prevent and repair damage to nature and strive to preserve the environment for future generations. The purpose of this study was to determine how the implementation of character education caring for the environment through the Adiwiyata Program for Kalibaru State Vocational High School students in the success of the Banyuwangi Merdeka Program from Plastics. The research method used in this research is qualitative. The subjects in this study were the principal, educators and students. Data collection was carried out by observation techniques, interview techniques, and documentation techniques. The data analysis technique used is an interactive analysis technique which includes data collection, data reduction, data presentation, then drawing a conclusion. The results showed that character education caring for the environment through the Adiwiyata program was in line with the Banyuwangi Regency government program, namely freedom from plastic and the program was running well. The program of activities includes clean Friday, healthy Friday, taqwa Friday, daily and weekly routine pickets and programs free from plastic waste. In addition, it also limits the sale of food using plastic media, and urges school residents to bring food and drink containers from home. Through this program, students care more about preserving and cleaning the environment. This is evident from the clean and beautiful conditions of the Kalibaru State Vocational School environment.

\section{Keyword: Character education caring for the environment; Adiwiyata; Freedom from plastics}

\section{PENDAHULUAN}

Di era globalisasi saat ini, permasalahan lingkungan menjadi permasalahan yang umum di Indonesia. Meningkatnya jumlah populasi manusia membuat kebutuhuan manusia menjadi meningkat. Terjadinya eksploitasi sumber daya alam dan lahan yang berlebihan demi memenuhi kebutuhan manusia atau demi memenuhi keserakahan manusia memiliki dampak yang merugikan bagi manusia.Hal tersebut menjadi satu dari sekian banyak permasalahan lingkungan yang terjadi di Indonesia. Selain permasalahan tersebut, dengan kemajuan transportasi dan banyaknya kendaraan juga menyebabkan polusi udara di lingkungan. Lemahnya kesadaran terhadap lingkungan masih sering terjadi.Sebagian manusia seakan masih bersikap acuh dan terkesan tidak peduli terhadap lingkungan.

Perilaku yang masih sering di jumpai di lingkungan sekitar yakni membuang sampah di sembarang tempat dan masih banyak manusia yang menggunakan barang berbahan plastik seperti sedotan plastik maupun kantong belanja plastik yang hanya digunakan sekali pakai yang berakhir menjadi sampah, padahal sampah plastik plastik merupakan bahan yang tidak dapat diuraikan. Perilaku di atas dapat 
menumbulkan berbagai macam bencana seperti banjir dan tanah longsor yang merugikan manusia.Contoh lain di lingkungan sekitar terutama di jenjang pendidikan yakni banyak sekolah yang sudah menerapkan kebersihan lingkungan namun belum secara tegas dan masih cenderung mengandalkan penjaga sekolah atau petugas kebersihan untuk membersihkan lingkungan sekolah.

Manusia dalam memenuhi kebutuhan sangat bergantung dengan alam, apabila manusia membiarkan kerusakan terjadi secara terus menerus maka manusia akan kehilangan sumber kehidupan.Guna membentuk generasi yang sadar tentang arti penting lingkungan bagi keberlangsungan hidup manusia, perlu adanya usaha yang dilakukan untuk mengarahkan dan menjadi seseorang mempunyai jiwa yang peduli dan mencintai lingkungan alam sekitar.Sikap yang masih kerap ditemukan di lingkungan sekililing yakni membuang sampah di sembarang tempat dan masih banyak manusia yang memakai benda berbahan plastik seperti, sedotan plastik maupun belanja plastik yang hanya digunakan sekali pakai yang berakhir menjadi sampah, padahal sampah plastik merupakan bahan yang tidak dapat diuraikan.

Menurut Daryanto dan Suryatri (dalam meidita candra milutasari, 2019) Perilaku untuk menjaga lingkungan hidup telah di atur dalam Undang-Undang Nomor 23 tahun 1997 tentang pengurusan lingkungan hidup yang berbunyi setiap orang berkewajiban menjaga kelestarian guna untuk lingkungan hidup serta mencegah dan menanggulangi pencemaran dan perusakan lingkungan hidup generasi mendatang.

Mengatasi kasus dan darurat lingkungan yang berjalan saat ini dan masa yang akan datang tidak bisa hanya dilakukan melalui strategi pendidikan moral saja. Pendidikan karakter peduli lingkungan merupakan salah satu dari 18 karakter yang di tetapkan oleh Pusat Kurikulum Kementrian Pendidikan Nasional. Karakter peduli lingkungan mempunyai pengertian perilaku dan tindakan yang selalu berupaya menghalangi keburukan pada lingkungan alam disekitarnya dan melembarkan cara-cara untuk memperbaiki keburukan alam yang sudah berjalan.

Indah Kusuma et al, (2018) Pembangunan nasional dibidang pendidikan merupakan usaha mencerdaskan kehidupan bangsa dan meningkatkan kualitas manusia Indonesia dalam mewujudkan masyarakat yang maju, adil, dan makmur. Pembahasan yang di hadapi oleh bangsa Indonesia adalah melemahnya mutu pendidikan. Pada dasarnya terdapat berbagai aspek yang memperburuk keberhasilan mutu pendidikan, antara lain; pendidik, peserta didik, sarana dan prasarana lingkungan pendidikan kurikulum dan salah satu aspek yang melemahnya keberhasilan peserta didik adalah faktor lingkungan.Keadaan lingkungan sekolah yang baik bertujuan merupakan wadah kegiatan pembelajaran yang kondusif dan meningkatkan pembudayaan pada warga sekolah untuk turut bertanggung jawab dalam cara-cara pengaman lingkungan hidup dan pembentukan berkelanjutan.

Program Adiwiyata merupakan program yang sangat relevan untuk menjawab permasalahan lingkungan yang semakin berkembang, karena program Adiwiyata menekankan pada Aspek pembentukan karakter warga sekolah untuk berpartisipasi aktif dalam mengelola lingkungan secara baik.

Adiwiyata Menurut Sumarsono dan Mukani (2017), mempunyai gambaran sebagai tempat yang baik dan ideal lantaran dapat diperoleh segenap ilmu pengetahuan dan beragam norma serta etika yang merupakan dasar manusia menuju terwujudnya kesejahteraan hidup dan menuju cita-cita pembentukan berkelanjutan. Adiwiyata dicanangkan untuk mendorong dan menata sekolah-sekolah di Indonesia agar mampu mengelola upaya pemerintah menuju pelestariaan lingkungan dan pembangunan berkelanjutan bagi kepentingan generasi sekarang maupun yang akan datang. Mengembangkan masyarakat berkarakter peduli lingkungan di mungkinkan dapat efektif melalui pendidikan karakter peduli lingkungan disekolah.

Indah kusuma et al (2018) menjelaskan Program adiwiyata dilaksanakan guna mewujudkan warga sekolah yang bertanggung jawab dalam upaya perlindungan dan pengelolaan lingkungan hidup melalui tata kelola sekolah yang baik untuk mendukung pembangunanberkelanjutan.

Program adiwiyata menggabungkan pembelajaran dan tindakan sehingga memberikan metode yang efektif untuk mengubah perilaku. Adapun pedomanan pelaksanaan untuk program adiwiyata yang ditetapkan 4 kompenen program yang menjadi satu kesatuan utuh dalam mencapai sekolah adiwiyata yaitu:

1. Kebijakan berwawasan lingkungan

2. Pelaksanaan kurikulum berbasis lingkungan

3. Kegiatan lingkungan berbasis partisipatif

4. Pengelolaan sarana pendukung ramah lingkungan.

Program Adiwiyata adalah salah satu program Kementrian Lingkungan Hidup yang merupakan Implementasi Permen Lingkungan Hidup No.02 Tahun 2009. Program ini merupakan suatu bentuk penghargaan yang diberikan oleh pemerintah kepada lembaga pendidikan formal yang di nilai berjasa dalam mengembangkan pendidikan dalam mengembangkan pendidikan lingkungan hidup.

Adiwiyata sebagai sebuah program sekolah bertujuan menciptakan kondisi yang baik bagi sekolah untuk menjadi tempat pembelajaran dan tempat penyadran warga sekolah baik pendidik,tenaga kependidikan, peserta didik maupun masyarakat sekitar sekolah, dalam upaya mendorong penyelamatan lingkungan dan pembangunan berkelanjutan yang akhirnya dapat mewujudkan sekolah yang peduli dan berbudaya lingkungan. SMK Negeri Kalibaru 
merupakan salahsatu sekolah di Kabupaten Banyuwangi yang menyandang predikat sekolah Adiwiyata. Didalam pelaksanaanya sekolah juga menyelaraskan program yang telah di luncurkan oleh Bupati Banyuwangi yaitu "Merdeka dari Plastik".

Program adiwiyata di harapakan mampu membentuk karakter peduli lingkungan dari hal yang paling kecil seperti membuang sampah pada tempatnya,membedakan pembuangan sampah yang organik dan non organik, memanfaatkan kertas yang tidak terpakai, mengehmata pemakaian air, membersihkan lingkungan dan lain-lain.

Berdasarkan uraian diatas Tujuan penelitian ini adalah untuk mengetahui Bagaimanakah implementasi pendidikan karakter peduli lingkungan melalui Program Adiwiyata pada peserta didik di SMK Negeri Kalibaru dalam menyuksekan Program Banyuwangi Merdeka dari Plastik

\section{METODE}

Penelitian ini merupakan penelitian deskriptif kualitatif. Penelitian kualitatif adalah prosedur penelitian yang menghasilkan kata-kata tertulis atau lisan dari orang-orang dan perilaku yang dapat diamati (Moleong, 2007). Subyek penelitian adalah kepala sekolah, Pendidik, karyawan dan yang terakhir peserta didik.

Penelitian ini bertujuan untuk mendapat gambaran dan informasi yang lebih jelas, lengkap, serta memungkinkan dan mudah bagi peneliti untuk melakukan penelitian observasi. Oleh karena itu, maka penulis menetapkan lokasi penelitian adalah tempat di mana penelitian akan dilakukan. Dalam hal ini, lokasi penelitian terletak di SMK Negeri Kalibaru Kabupaten Banyuwangi. Subyek dalam penelitian ini adalah Kepala Sekolah, Pendidik dan peserta didik. Pengumpulan data dilakukan dengan teknik observasi, teknik wawancara, dan teknik dokumentasi.

Teknik analisis data yang digunakan adalah teknik analisis interaktif yang meliputi pengumpulan data, reduksi data, penyajian data, kemudian menarik suatu kesimpulan

\section{HASIL DAN PEMBAHASAN}

Kabupaten Banyuwangi terletak di Propinsi Jawa Timur, yang berada di ujung paling timur pulau Jawa. Kabupaten Banyuwangi merupakan Kabupaten terluas di Jawa Timur sekaligus menjadi terluas dipulau Jawa dengan luas mencapai kurang lebih 5.782,50 km2.

Pemerintah Kabupaten Banyuwangi memiliki program kepedulian dalam menjaga lingkungan hidup, salah satu diantaranya adalah: 1). Banyuwangi menyiapkan kolaborasi program pengelolahan sampah di desa dan destinasi wisata, 2). Banyuwangi merdeka dari plastik.

Salah satu program Pemerintah Kabupaten Banyuwangi yaitu "Merdeka dari Plastik" yang telah dicanangkan yang bertepatan dengan hari ulang tahun
Republik Indonesia yang ke-74 tahun, Pemerintah Kabupaten Banyuwangi mengadakan sebuah program untuk melakukan pembenahan kota Banyuwangi yang diluncurkan langsung oleh Bapak Abdullah Azwar Anas selaku Bupati Banyuwangi sebagai upaya mengurangi sampah plastik. Maksud dari Merdeka dari plastik inilah adalah bebas sampah plastik.

Merdeka dari Plastik adalah sebuah program yang mengajak masyarakat banyuwangi untuk mengurangi Volume Plastik yang di hasilkan setiap harinya. Dasar pembentukan Program ini di luncurkan oleh bupati banyuwangi yaitu Abdullah Azwar Anas meluncurkan Program "Merdeka Dari Plastik" sebagai upaya mengurangi sampah plastik. Program ini di luncurkan bersamaan di hari Ulang tahun ke-74 Republik Indonesia, kegiatan peringatan hari ploklamasi kemerdekaan RI di jadikan momentum oleh Pemerintah Kabupaten Banyuwangi untuk melalukan pembenahan kota dengan peluncuran program merdeka dari plastik. Seperti telah di ketahui bahwasanya plastik ini terurai lama ada yang 400 bahkan hingga 1.000 tahun. (Banyuwangikab.go.id:17 Agustus 2019)

Surat Edaran Gubernur Jawa Timur Nomor 660/9184/11.3/2018 tanggal 15 agusus 2018. Perihal pembatasan sampah plastik.Sebagai tahapan awal, program bebas sampah plastik diterapkan di dua ruang publik terbesar diwilayah Banyuwangi yaitu adalah Taman Sritanjung dan Taman Blambangan karena di tempat tersebut tempat titik kumpul masyarakat yang selalu terdapat event seni budaya yang menjadikan titik kumpul banyak orang. Dengan ini bupati banyuwangi Abdullah azwar anas langsung mengajak masyarakatnya untuk mengambil aksi nyata karena lama kelamaan kita akan hidup di atas plastik Di sudut Taman Blambangan dibentangkan kain yang bertuliskan "Revolusi mental menuju Banyuwangi Merdeka dari Plastik". Bupati Banyuwangi menghimbau untuk hindari penggunaan plastik. Karena plastik adalah permasalahan yang global dan mendapat perhatian serius dari dunia..

Warga dan pedagang yang disekitar taman Blambangan mulai mengurangi penggunaan media plastik misalnya tidak menggunakan kantong plastik sebagai pembungkus atau penyaji makanan, warga dan pedagang di edukasi untuk menjauhi plastik seperti tidak menggunakan sedotan diminuman atau menggunakan kertas daun ulang untuk pembungkus makanan. Sehingga banyak pedagang yang sudah mulai paham untuk mengurangi menjual makanan dalam kemasan plastik. Selain itu juga dilakukan pemilahan sampah mana organik dan mana pula nonorganik dari pembungkusnya dengan tujuan untuk memudahkan pengelolahan sampah.

Perencanaan merupakan keseluruhan proses pemikiran penentuan semua aktivitas yang akan dilakukan pada masa yang akan datang dalam rangka mencapai tujuan. Maka dari itu diperlukan kemampuan untuk mengadakan visualisasi dan melihat kedepan guna 
merumuskan suatu pola tindakan untuk masa mendatang. Adanya perencanaan merupakan hal yang harus ada dalam setiap kegiatan, perencanaan dituangkan dalam konsep yang jelas. Bentuk perencanan pendidikan karakter yang dilakukan baik dalam bentuk kegiatan pembelajaran maupun kegiatan diluar sekolah seperti budaya sekolah dan kegiatan ektrakurikuler yakni cipta usaha dengan memasukan dan pengintegrasian nilai-nilai karakter yang di kembangkan di SMK Negeri Kalibaru.

Sebagai sekolah yang menyandang status sekolah Adiwiayata, SMK Negeri Kalibaru tentu sangat mendukung atas program tersebut, karena gerakan ini merupakan salah satu wahana untuk meningkatkan kesadaran dan pemahaman seluruh warga sekolah akan kebersihan dan kepudlian terhadap lingkungan, karena kegiatan tersebut banyak nilai-nilai karakter posistiv yang bisa dikembangkan diantaranya adalah kerjasama,gotong royong peduli lingkungan dan pentingnya hidup sehat.

Adiwiyata merupakan pendidikan berkelanjutan bagi sekolah maupun masyarakat untuk menjaga lingkungan sekitar. Program adiwiyata di SMK Negeri Kalibaru dijalankan sama semua elemen dengan partisipatif, khususnya di sekolah SMK Negeri Kalibaru, yakni kepala sekolah dan peserta didik hingga karyawannya.

Pelaksanaan Program Adiwiyata di letakkan pada dua prinsip dasar berikut ini :

1. Partisipatif

Komunitas sekolah terlibat dalam manajemen sekolah yang meliputi keseleuruhan proses perencaanaa, pelaksanaan danevaluasi sesuai tanggung jawab dan peran. Keterlibatan warga sekolah dalam implementasi program Adiwiyata menjadi poin penting guna mensukseskan program tersebut.Warga sekolah dalam hal ini adalah seluruh kompenen sekolah yang meliputi kepala sekolah, guru, pegawai, karyawan kantin pun di tuntut berperan aktif dalam mencipatakan budaya peduli terhadap lingkungan.

2. Berkelanjutan

Pelaksanaan program Adiwiyata harus didasarkan pada proses manajemen yang baik. Baik itu dari segi perencaanaan, pengorganisasian, pelaksanaan, monitoring, dan evaluasi.Seluruh kegiatan harus di lakukan secara terencana dan berkelanjutan. Oleh karena itu, perlu adanya monitoring dan evaluasi dari setiap proses yang di lakukan. Monitoring dan Evaluasi berfungsi untuk memantau dan memberikan penilaian terhadap implementasi program Adiwiyata sehingga masukan dan perbaikan kedepannya

Dalam hal ini meskipun letaknya sekolah SMK Negeri Kalibaru berdekatan dengan jalan nasional tetapi tidak terganggu adanya polusi asap kendaraan di karenakan banyak pepohonan yang ditanam di lingkungan sekolah, semakin banyak pula pohon yang ditanam semakin banyak pula oksigen yang di hasilkan. Dengan adanya pepohonan yang banyak dan suasana yang asri peserta didik bisa menjadikan media laboratorium pembelajaran diluar ruangan sehingga peserta didik tidak bosan melakukan pembelajaran di kelas saja

Pendidikan karakter melingkupi kegiatan memberdayakan peserta didik agar mampu berperilaku mandiri dan berbudi pekerti dalam mengembangkan segala potensi yang dimiliki sehingga dapat menjadi pribadi yang cerdas secara intelektual dan cerdas secara moral.

Masnur Muslich (2011) menyatakan bahwa karakter merupakan nilai- nilai perilaku manusia yang berhubungan dengan Tuhan Yang Maha Esa,diri sendiri, sesama manusia, lingkungan,dan kebangsaan yang terwujud denganpikiran,sikap, perasaan,dan perbuatan berdasarkan norma agama, hukum, tata karma,budaya, dan adat istiadat..

Dharma Kesuma (dalam Pipit Uliana \& Rr Nanik Setyowati, 2013) mendefinisikan pendidikan karakter sebagai pembelajaran yang mengarah pada penguatan dan pengembangan perilaku anak secara utuh yang didasakan pada suatu nilai tertentu yang dirujuk oleh sekolah.

Sebagai pendidik dalam membentuk karakter peserta didik peduli lingkungan tentunya harus termuat dalam kegiatan pembelajaran yang dituangkan dalam RPP dan terintegrasi pada setiap mata pelajaran dan kegiatan luar pembelajaran seperti ektrakurikuler.

Mohamad Mustari (2014) menyebut karakter peduli lingkungan sebagai karakter ekologis. Ekologis adalah sikap dan tindakan yang selalui berupaya mencegah kerusakan pada lingkungan alam dan sekiatrnya, serta mengembangkan upaya-upaya untuk memperbaiki kerusakan alam yang sudah terjadi dan selalu memberi bantuan bagi orang lain yang membutuhkan

Dengan demikian pembelajaran selain untuk menjadikan peserta didik menguasi kompetensi dasar yang di targetkan, juga di rancang dan ditargetkan untuk menjadikan peserta didik mengenal, menyadari peduli dan menginternalisasikan nilai-nilai dan menjadikan perilaku. Melalui kegiatan pembelajaran diharapkan peserta didik dapat menjadi pribadi yang cerdas secara intelektual dan cerdas moral. Mengingat fungsi pendidikan karakter peduli lingkungan tersebut sangat penting maka perlu dilakukan kegiatan secara rutin melalui kegiatan sekolah.

Dari hasil penelitian diperoleh data bahwa yang dilakukan sekolah dalam mewujudkan pendidikan karakter peduli lingkungan yaitu melalui program:

1. Program Jum'at bersih

2. Program Jum'at sehat

3. Progam Jum'at taqwa

4. Progam piket kelas harian 


\section{Program bebas dari sampah plastik}

Program Jumat bersih ini adalah salah satu inovasi dari sekolah SMK Negeri Kalibaru, dimana budaya jum'at bersih ini adalah bagian dari peduli lingkungan dimana sikap dan tindakan yang dilakukan oleh siswa serta warga sekolah berupaya mencegah keruskan pada lingkungan alam sekitarnya, dan menjadi bagian dalam upaya untuk memperbaiki kerusakan alam yang sudah terjadi.

Seluruh warga sekolah mulai dari karyawan, siswa, guru, dan Kepala Sekolah melaksanakan kerja bhakti membersihkan halaman sekolah, perpustakaan, mushollah, ruang kelas, taman, ruang guru, ruang praktik, dan sekitar sekolah. Budaya Jum'at bersih dapat menjadi kebiasaan yang sangat baik dan menyehatkan dengan berbagai manfaat antaralain menumbuhkan cinta dan peduli terhadap lingkungan sekolah. Tujuan utama dari kegiatan Jum'at bersih adalah dapat menumbuhkan rasa memiliki dikalangan siswa akan pentingnya kebersihan lingkungan demi kesehatan, sehingga suasana belajar akan terasa nyaman dan aman, kondisi sekolah juga dapat terpelihara dengan baik. Pola perilaku hidup bersih dapat menentukan pola hidup sehat khususnya di lingkungan tempat belajar, karena lingkungan yang sehat dapat meningkatkan konsentrasi belajar yang lebih tinggi dan mendukung sikap belajar yang antusias, sehingga mempengaruhi produktifitas siswa serta guru dalam proses kegiatan belajar mengajar.

Selanjutnya adalah program Jum'at sehat dimana didalam program ini siswa dan warga sekolah melakukan olahraga senam dan jalan sehat, Program Jum'at Sehat memiliki dua kegiatan utama, yaitu senam dan jalan sehat. pelaksanaan Jumat Sehat dilaksanakan pada pagi hari karena udara masih segar dan belum begitu panas. Kegiatan dilaksanakan tepat pukul 07.00 WIB bertempat di lhalaman sekolah SMK Negeri Kalibaru dan kegiatan ini diikuti oleh semua warga sekolah. Dalam pelaksanaannya sebagian guru dan karyawan mendampingi kegiatan jalan sehat dan sebagain lagi mendampingi kegiatan senam. Kegiatan ini bukan hanya bertujuan untuk menjaga fisik siswa tetapi juga lebih mengenalkan lingkungan sekitar dan peka terhadap gejala sosial yang ada dilingkungan sekolah. Selain itu juga agar peserta didik tidak bosan dan jenuh karena keseharian belajar didalam kelas.

Kemudian, program jum'at taqwa adalah yang didalamnya siswa melakukan kegiatan mengaji dan sholawatan yang dilakukan di mushola sekolah. Tujuan dari program Jum'at taqwa ini adalah untuk mempertebal rasa keiimanan dan ketaqwaan siswa. Dengan Jum'at taqwa ini dapat mengembangan nilainilai keimanan, keislaman, sosial dan membentuk karakter siswa yang religius. Religius sikap dan gemar membaca dalam melaksanakan ajaran agama yang dianutnya. Toleran terhadap pelaksanaan ibadah agama lain, dan hidup rukun dengan pemeluk agama lain.
Religius adalah proses mengikat kembali atau bisa dikatakan dengan tradisi, sistem yang mengatur tata keimanan (kepercayaan) dan kepribadian kuasa serta tata kaidah yang berhubungan dengan pergaulan manusia dan manusia serta lingkungannya.

Selanjutnya program piket harian kelas yang dilakukan sebelum dan sesudah pembelajaran di mulai. Siswa yang mendapat tugas piket sesuai jadwal, harus melaksanakan tugasnya dengan baik. Oleh sebab itu piket kelas datang lebih awal dari siswa yang lainnya. Adapaun yang dilakukan siswa saat piket yaitu membersihkan, mengepel dan menghapus papan tulis yang kotor agar ketika pembelajaran di mulai kelas sudah bersih.

Sebagai motivasi dan apresiasi kepada kelas Waka Kesiswaan mengadakan lomba kebersihan kelas secara rutin, dimana dalam lomba kebersihan ini diberikan penghargaan yaitu berupa bendera hijau dan alat kebersihan bagi kelas yang bersih tetapi bagi kelas yang kotor di beri bendera hitam.

Selanjutnya yang terakhir yaitu program bebas dari sampah plastik. Dimana dalam program ini pihak sekolah melarang Seluruh warga sekolah mulai dari karyawan, siswa, guru, dan Kepala Sekolah untuk tidak membeli makanan dan minuman kemasan yang berbahan plastik. Selanjutnya siswa dan warga sekolah diwajibkan untuk membawa tempat makan atau minum yang dapat digunakan berulang-ulang. Selain itu kebijakan sekolah terkait dengan program bebas dari sampah plastik ini juga diberlakukan kepada semua penjual dikantin sekolah agar tidak menggunakan kemasan plastik atau kantong plastik agar mengurangi jumlah sampah plastik yang ada. Jika ada yang melanggar maka pihak sekolah akan memberikan sangsi yang tegas.

Selain itu program bebas dari sampah plastik ini juga diterapkan saat sekolah mengadakan rapat tidak menggunakan air minum kemasan sehingga dapat mengurangi jumlah sampah plastik yang ada. Karena hal ini dianggap dapat memberikan contoh tauladan yang baik kepada semua peserta didik agar bisa mencontohnya.

Kebehasilan implementasi pendidikan karakter peduli lingkungan SMK Negeri Kalibaru tersebut tidak terlepas dari kebijakan kepala sekolah, karena kepala sekolah ini kunci utama dalam terlaksanya programprogram tersebut agar bisa berjalan dengan baik. Didalam pelaksanaanya juga terdapat kerja sama yang baik dengan tim adiwiyata serta warga sekolah dalam berkordinasi dan bekonsolidasi.

Keberhasilan yang dicapai juga tidak bisa dilepaskan dari permasalahan-permasalahan yang ada diantaranya masih ada warga sekolah yang melanggar dan tidak melaksanakan ketentuan dan aturan yang dibuat oleh sekolah Namun demikian dalam implementasi pendidikan karakter peduli lingkungan mengalami beberapa hambatan-hambatan, akan tetapi 
pihak sekolah mempunyai strategi atau upaya dalam menghadapi hal ini dengan cara melakukan pendekatan dengan memberi motivasi dan memberi teguran, serta membatasi penjualan makanan yang berbahan plastik terus menghimbau warga sekolah khususnya peserta agar membawa kotak makan dan minuman botol yang bisa di gunakan berulang-ulang.

Selain itu pendidikan karakter peduli lingkungan di SMK Negeri Kalibaru juga sudah ditanamkan kepada peserta didik sejak dalam masa orentasi peserta didik (MOS). Melalui MOS ini peserta didik dibekali dengan pengetahuan tentang pentingnya kesehatan, kebersihan dan cara menjaga alam agar tetap lestari. Salah satunya yaitu peserta didik di wajibkan membawa tanaman dari rumah untuk dirawat di depan kelas mereka masingmasing, kerja bakti membersihkan lingkungan sekolah, jalan sehat dan senam bersama.

Selanjutnya sekolah juga menyediakan fasilitas pembuangan sampah yaitu berupa tempat sampah organik dan non organik yang nantinya peserta didik bisa membuang sampah pada tempatnya. Sampah organik ini nantinya di daur ulang sebagai pupuk kompos dan untuk sampah non organik di daur ulang sebagai kerajinan melalui ektrakurikuler cipta usaha. Ektrakurikuler cipta usaha inilah yang mendaur ulang sampah-sampah tersebut..

Dari pemaparan diatas dapat disimpulkan bahwa SMK Negeri Kalibaru merupakan salah satu sekolah di Kabupaten Banyuwangi yang sudah mengimplementasikan pendidikan karakter peduli lingkungan melalui Program Adiwiyata dengan baik. Apa yang sudah dilakukan di SMK Negeri Kalibaru sejalan dan selaras dengan program Pemerintah Kabupaten Banyuwangi Merdeka dari Plastik.

\section{SIMPULAN}

Penerapan pendidikan karakter peduli lingkungan melalui program Adiwiyata sejalan dengan program pemerintah Kabupaten Banyuwangi yaitu merdeka dari plastik dan program tersebut berjalan dengan baik. Adapun program kegiatan sekolah SMK Negeri kalibaru tersebut meliputi program Jum'at bersih, Jum'at sehat, Jum'at taqwa, piket rutin harian dan mingguan, dan bebas dari sampah plastik. Selain itu juga membatasi penjualan makanan oleh pedagang kantin sekolah yang menggunakan media plastik, serta menghimbau agar warga sekolah membawa tempat makanan dan minuman dari rumah. Melalui program tersebut peserta didik lebih peduli menjaga kelestarian dan kebersihan lingkungan ini terbukti dari kondisi lingkungan sekolah SMK Negeri Kalibaru yang bersih dan asri.

\section{DAFTAR PUSTAKA}

Moleong, L.JJ. 2007. Metodologi Penelitian Kualitatif. Penerbit PT Remaja Rosdakarya Offset. Bandung
Muslich Manshur. 2011. Pendidikan Karakter: Menjawab Tantangan Krisis Multidimensional. Penerbit Bumi Aksara, Bandung

Mustari Mohammad. 2014 . Nilai Karakter Refleksi Untuk Pendidikan. Penerbit Rajawali Pos. Jakarta.

Milutasari, Candra Meidita. 2019. Pembinaan karakter peduli lingkungan melalui program adiwiyata di SD Negeri 16 purwodadi Surakarta: Skripsi thesis Universitas Muhammadiyah Surakarta.

Nurjanah, Bedjo sujanto, indah kusuma. 2018. Implementasi program sekolah adiwiyata dalam peningkatan mutu pendidikan di SDN tanah tinggi 3 kota tanggerang: Universitas Negeri Jakarta. Jakarta.

Uliana, Pipit \& Rr Nanik Setyowati, 2013. Implementasi Pendidikan Karakter Melalui kultur Sekolah pada peserta didik kelas Xl di SMA Negeri 1 Gedangan Sidoarjo. Jurnal Kajian Moral dan kewarganegaraa Vol.1 No.1 .

Sumarsono Teto, Mukani. 2017.Pendidikan karakter peduli lingkungan berbasis adiwiyata pada mata pelajaran fiqih di MTsN tambak beras jombang: Jurnal Pendidikan Agama Islam (Journal of Islamic Education Studies) Vol.5 No. 2

Surat Edaran Gubernur Jawa Timur Nomor 660/9184/11.3/2018 tanggal 15 agusus 2018. Tentang pembatatasan sampah plastik

https://banyuwangikab.go.id/berita-daerah/banyuwangicanangkan-merdeka-sampah-plastik-tahap-awaldi-2-ruang-publik-terbesar.html

https://jdih.banyuwangikab.go.id/dokumen/surat edaran/ surat_edaran_no_660_412_429.104_2019_001_.p df 